\title{
Uncommon traumatic anterior aortic dissection in the context of a blunt trauma
}

\author{
Michael Hall, ${ }^{1}$ Angelo La Valle, ${ }^{1}$ Ramzi Freij, ${ }_{1}$ A Brooks ${ }^{3}$
}

'General Surgery, Queen's Medical Centre, Nottingham, UK ${ }^{2}$ Accident and Emergency, Queen's Medical Centre Nottingham University Hospital NHS Trust, Nottingham, UK ${ }^{3}$ Surgery, Queen's Medical Centre, Nottingham, UK

\section{Correspondence to} Dr Angelo La Valle; an-lavalle@hotmail.it

Accepted 30 May 2021

\section{DESCRIPTION}

This 79-year-old woman was involved in a road traffic collision in which another driver rear-ended her stationary car at a speed of around $70 \mathrm{~m} / \mathrm{h}$. She was transferred to the nearest Major Trauma Centre, where her observations remained stable and initial primary survey was unremarkable. She had a full trauma CT that revealed extensive bilateral rib fractures with flail of $8+9$ on the left, a C4-5 body fracture and, most significantly an acute traumatic pseudoaneurysm of the thoracic aorta and associated pneumomediastinum.

The CT images show transverse and coronal views of this pseudoaneurysm. On the coronal views(figure 1), you can see a bulging of the anterior wall of the thoracic aorta, just below the level of the isthmus. On the transverse view(figure 2), you can see the lumen of the aorta (indicated by an arrow), with a false lumen demonstrating dissection of this vessel.

A discussion was held with interventional radiology, who recommended endovascular stenting of the injured aorta under general anaesthetic to minimise the chances of future rupture. The anaesthetic team however deemed her very high risk given her trauma

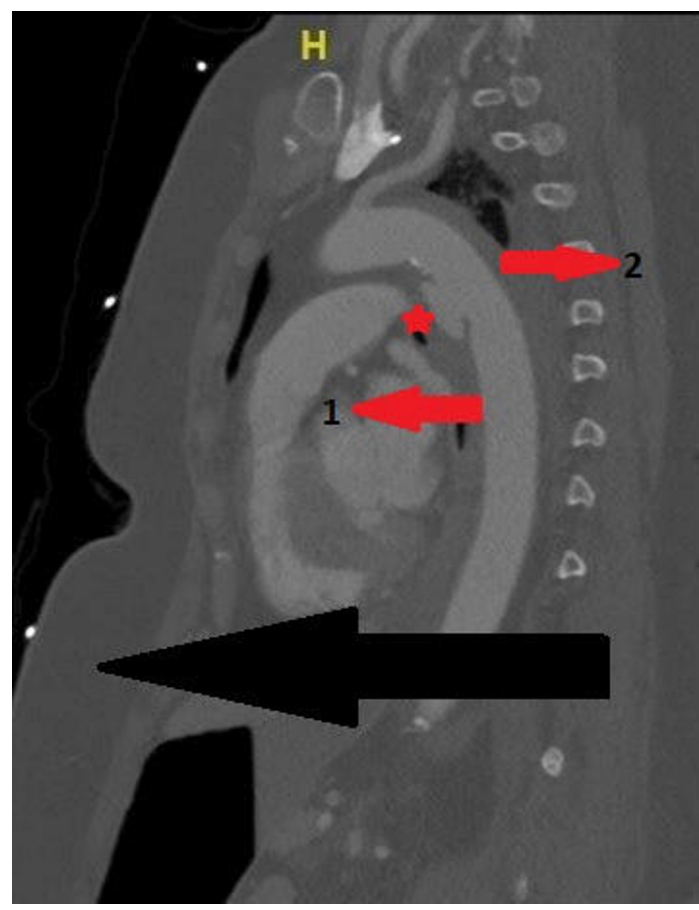

Figure 1 This sagittal view shows an outpouching of the thoracic aorta along the underside of the aortic isthmus, in keeping with an anterior traumatic pseudoaneurysm.

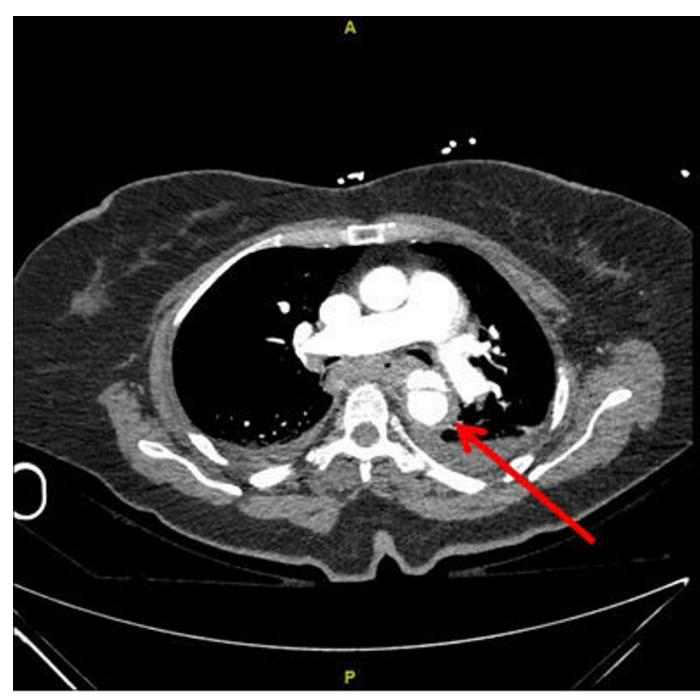

Figure 2 Axial view. The pseudoaneurysm sac measures $2.5 \times 1 \mathrm{~cm}$ and is indicated by the arrow. Surrounding periaortic haematoma and hyperdense fluid within the mediastinum and pleural spaces, in keeping with haemomediastinum and haemothorax.

burden coupled with her advanced age and significant pre-existing comorbidities. They advised us that she was unlikely to survive a general anaesthetic. This was discussed fully with the patient who did not want to risk a general anaesthetic, due to the low probability of survival, before she has had the chance to see her family. She was therefore admitted to the ward with an Aspen collar for her C4-5 fracture and

Learning points

- Beware of 'normal' observations in geriatric trauma-older people can present as haemodynamically stable following trauma despite significant injury due to polypharmacy, medical conditions such as hypertension or limited physiological reserve.

- Importance of multidisciplinary team (MDT) involvement in trauma-Major Trauma team, radiology, vascular and anaesthetics involved in making decision that she would be unsuitable for general anaesthesia and endovascular intervention due to poor physiological reserve with high trauma burden

- Ensure to involve the patient in decisions where possible. In this case, decision had been made by the MDT, but patient was in agreement with decision. 
epidural for pain relief from her ribs. Over the next day, she began to deteriorate with her breathing, and unfortunately passed away rapidly the following night, with high suspicion of rupture of her pseudoaneurysm.

In blunt trauma, this injury more commonly occurs from a deceleration injury and located around the aortic isthmus as this is the point where the thoracic aorta, which is relatively mobile, joins with the arch of aorta which is fixed..$^{12}$ The majority of patients with traumatic injury to the thoracic aorta tend to die on scene or before arrival to hospital. ${ }^{3}$ In this case, the patient arrived in an apparently stable condition, not showing any signs of obvious injury. It was only on CT scanning, which was done due to high impact trauma combined with old age and frailty that her injuries were picked up. On another occasion, this could very easily have been missed.

Twitter Angelo La Valle @AngeloLaValle6
Acknowledgements We would like to thank to Mr Brooks and Dr Freij for their support and encouragement in writing this report.

Contributors $\mathrm{MH}$ and ALV reviewed the literature on the subject, wrote the case report and selected the appropriate images. RF and AB reviewed the drafts and supervised the work.

Funding The authors have not declared a specific grant for this research from any funding agency in the public, commercial or not-for-profit sectors.

Competing interests None declared.

Patient consent for publication Parent(s)/guardian(s) consent obtained

Provenance and peer review Not commissioned; externally peer reviewed.

\section{REFERENCES}

1 Creasy JD, Chiles C, Routh WD, et al. Overview of traumatic injury of the thoracic aorta. Radiographics 1997:17:27-45.

$2 O^{\prime}$ Conor CE. Diagnosing traumatic rupture of the thoracic aorta in the emergency department. Emerg Med J 2004;21:414-9.

3 Teixeira PGR, Inaba K, Barmparas G, et al. Blunt thoracic aortic injuries: an autopsy study. J Trauma 2011;70:197-202

Copyright 2021 BMJ Publishing Group. All rights reserved. For permission to reuse any of this content visit

https://www.bmj.com/company/products-services/rights-and-licensing/permissions/

BMJ Case Report Fellows may re-use this article for personal use and teaching without any further permission.

Become a Fellow of BMJ Case Reports today and you can:

- Submit as many cases as you like

- Enjoy fast sympathetic peer review and rapid publication of accepted articles

- Access all the published articles

Re-use any of the published material for personal use and teaching without further permission

Customer Service

If you have any further queries about your subscription, please contact our customer services team on +44 (0) 2071111105 or via email at support@bmj.com.

Visit casereports.bmj.com for more articles like this and to become a Fellow 